\title{
Implementasi Model Sentra Bermain Peran Pada Anak Kelompok B Di TK IT Al-Hasna
}

\author{
Nur Hasanah \\ PIAUD IAIN Kudus \\ Email: nur.nahkhasanah@gmail.com
}

\begin{abstract}
Abstrak
Penelitian ini bertujuan untuk mendeskripsikan penerapan sentra bermain peran pada anak kelompok B di TK IT Al-Hasna Klaten. Penelitian ini menggunakan metode deskriptif dengan pendekatan kualitatif. Teknik pengumpulan data menggunakan observasi, wawancara dan dokumentasi. Subjek dalam penelitian ini adalah guru sentra bermain peran dan kepala sekolah di TK IT AL-Hasna Klaten. Tahapan analisis yang digunakan adalah reduksi data, display data, dan penarikan kesimpulan atau verifikasi. Hasil penelitian mendeskripsikan bahwa pelaksanaan sentra bermain peran sudah baik, guru sudah melakukan perencanaan sebelum sentra beramain peran dibuka. Guru dalam sentra bermain peran melakukan 4 pijakan yaitu, pijakan lingkungan main, pijakan sebelum main, pijakan selama main, dan pijakan setelah main. Adapun kendala yang dihadapi oleh guru adalah kurangnya pengetahuan guru sehingga guru kesulitan saat membuat kegiatan dan kurangnya sarana prasarana yang berkaitan dengan bermain peran. Upaya untuk mengatasi kendala adalah dengan memberikan pelatihan dan workshop terhadap guru sentra main peran untuk mengatasi kesulitan yang dialami oleh guru.

Kata kunci: Sentra bermain peran, Anak kelompok B

Abstract

This study aimed to describe the application of role playing centers in group $B$ children in TK IT Al-Hasna Klaten. This research used a descriptive method with a qualitative approach. Data collection techniques used observation, interviews and documentation. Subjects in this study were center teachers playing the role and the principal at TK IT AL-Hasna Klaten. The stages of analysis was used by data reduction, data display, and drawing conclusions or verification. The results of the study describe that the implementation of the role playing center is already good, the teacher has made plans before the center plays the role is opened. Teachers in the role playing center do four steps namely, playing environment, footing before playing, footing during play, and footing after playing. The obstacles faced by teachers are the lack of teacher knowledge so that teachers have difficulties when creating activities and the lack of infrastructure related to playing roles. Efforts to overcome obstacles was to provide training and workshops for central teachers to play a role to overcome the difficulties experienced by teachers.
\end{abstract}

Keyword: The role playing center, Group children B 


\section{PENDAHULUAN}

Pendidikan Anak Usia Dini (PAUD) merupakan pendidikan yang sangat penting untuk mengembangkan seluruh potensi yang dimiliki anak usia dini melalui berbagai pemberian rangsangan dari guru, orang dewasa dan atau lingkungan sekitar. Pembelajaran yang ada di PAUD adalah dengan kegiatan bermain sambil belajar yang menyenangkan, khususnya anak usia 6 tahun pertama apabila tidak mendapat rangsangan yang maksimal dengan berbagai kegiatan pembelajaran maka potensi kecerdasannya tidak dapat berkembang secara optimal, karena pada masa inilah dinamakan sebagai masa golden age, masa paling bagus untuk mengambangkan potensi anak. Salah satu lingkungan anak adalah lingkungan sekolah, sehingga lingkungan sekolah ini harus memberikan stimulasi yang tepat bagi anak usia dini. Model pembelajaran di PAUD menjadi sangat penting karena merupakan salah satu aspek yang harus dimiliki oleh sekolah, model pembelajaran sentra merupakan model pembelajaran di PAUD yang bisa mengembangkan potensi kecerdasan anak.

Model Pembelajaran merupakan suatu rancangan untuk menggambarkan rincian dan penciptaan lingkungan yang menjadikan peserta didik untuk berinteraksi dalam pembelajaran sehingga terjadi perubahan atau perkembangan pada diri peserta didik. Komponen model pembelajaran meliputi konsep, tujuan pembelajaran, materi atau tema, langkah-langkah metode, alat atau sumber belajar, dan teknik evaluasi (Widyatmoko, 2011:3). Trianto (2010:21) menyatakan bahwa "model adalah suatu objek atau konsep yang digunakan untuk merepresentasikan sesuatu hal". Istilah model dapat diartikan sebagai tampilan grafis, prosedur kerja yang teratur atau sistematis, serta mengandung pemikiran brsifat uraian atau penjelasan berikut saran. Semua ini mengacu pada bagaimana penyelenggaraan proses belajar yang baik. Sedangkan model pembelajaran menurut Hamzah (2009:5) adalah suatu kegiatan yang berupaya membelajarkan siswa secara terintegrasi dengan memperhitungkan faktor lingkungan belajar, karakteristik siswa, karakteristik bidang studi serta berbagai strategi pembelajaran, baik penyampaian, pengelolaan, maupun pengorganisasian pembelajaran.

Banyak sekali model-model pembelajaran yang digunakan di PAUD, pemilihan model pembelajaran yang ada disekolah yang digunakan ditentukan dan ditetapkan oleh pihak masing-masing sekolah tentunya sesuai dengan kebutuhan dan kemampuan sekolah. Beberapa model pembelajaran yang ada seperti model High Scope, Reggio Emillia, Montessori, Project Base, sementara di Indonesia model pembelajaran yang sering dikenal seperti model klasikal, model area, model sentra, model sudut, model kelompok dengan kegiatan pengaman. Model sentra adalah model yang dikembangkan Creative Curiculum mengelola kegiatan pembelajaran yang seimbang antara bimbingan guru dengan inisiatif anak. Model ini dikenalkan di Indonesia oleh Dr. Pamela Phelp dari (Creative Center For Childhood Research and Training) CCCRT Florida. Sentra ini kemudian di Indonesia diadopsi oleh drg. Wismiarti tamin, yaitu pendiri sekolah Al-Falah di Ciracas, Jakarta Timur tahun 1996 kemudian merambah di sekolah-sekolah lain diberbagai daerah dan sekarang dianggap sebagai model pembelajaran yang paling populer bagi sekolah-sekolah unggulan. Model 
pembelajaran sentra di populerkan oleh tokoh inovasi pendidikan Eropa pada abad XX, Maria Montessori yang menekankan pada kegiatan bermain diabandingkan dengan belajar membaca, menulis dan berhitung (calistung), Martuti (2010: 77) menyatakan bahwa model sentra ini merupakan suatu model dalam penyelenggaraan pendidikan anak usia dini yang dikembangkan berdasakan hasil kajian teoritis dan pengalaman empiris.

Menurut Noorlaila (2010: 65) model sentra merupakan pengembangan model Mentessori, High Scope dan Reggio Emilia. Melalui model sentra ini maka guru memfasilitasi anak mengembangkan kecakapan berpikir aktif dan anak diberi keleluasaan untuk melakukan berbagai kegiatan untuk mendapatkan pengalaman tentang dunia sekelilingnya (Farida Yusuf, 2015: 12-13). Sentra yang dikembangkannya tidak berbeda dengan sistem area. Perbedaan tampak dalam pengelolaan kelas. Dalam model area semua anak bebas bergerak di semua area yang dikelola oleh seorang guru, sementara di sentra anak masuk kedalam satu sentra selama satu hari. Sentra sendiri berasal dari kata "centre" berarti pusat. Sentra adalah pembelajaran terpadu yang terbaik, karena dapat membantu anak-anak mengembangkan seluruh kemampuannya secara bersamaan, anak-anak belajar berpartisipasi aktif, mengamati, dan berinteraksi dengan anak lainnya (Asmawati: 2015: 38). Pada model sentra anak bebas memilih bermain yang disiapkan dalam satu sentra. Sentra dilengkapi dengan 3 jenis kegiatan bermain, atau bisa lebih tergantung dengan jumlah anak dalam 1 sentra. Keragaman main atau disebut juga densitas main memfasilitasi untuk dapat memilih mainan sesuai dengan minatnya. Kelompok anak berpindah bermain dari satu sentra ke sentra lainnya setiap hari. Tiap sentra dikekola oleh seorang guru, guru inilah yang dinamakan sebagai guru sentra.

Model sentra merupakan model pembelajaran yang paling populer di PAUD Indonesia dikarenakan dari berbagai sumber jurnal ilmiah yang menyatakan bahwa model ini mampu meningkatkan berbagai aspek perkembangan anak. Sentra dibuat berdasarkan kebutuhan dan perkembangan anak, bisa jadi sentra-sentra yang diterapkan disetiap lembaga tidak sama. hal ini dikarenakan adanya kebutuhan yang berbeda di setiap lembaga. Menurut (Martuti, 2010: 82-84) terdapat beberapa macam sentra yang dapat diterapkan, diantaranya: sentra bermain peran, sentra balok, sentra imtaq, sentra persiapan, sentra seni,sentra olahtubuh, sentra bahan alam.

Sentra dibuat berdasarkan kebutuhan dan perkembangan anak, bisa jadi sentra-sentra yang diterapkan disetiap lembaga tidak sama. Hal ini dikarenakan adanya kebutuhan dan kemampuan yang berbeda di setiap lembaga. Sentra bermain peran merupakan salah satu sentra yang sangat menarik bagi anak-anak, sentra peran memfasilitasi anak untuk berfikir kreatif dan imajinatif, hal ini sesuai dengan perkembagan kognitif anak menurut Piaget, yang menyatakan bahwa anak adalah individu yang imajinatif. Sentra bermain peran adalah sentra yang biasanya menjadi unggulan bagi sekolah karena permainan main peran membuat anak bermain peran baik mikro ataupun bermain peran makro. Anak bisa berpura-pura menjadi apapun sesuai dengan tema yang telah ditentukan, anak bermain peran menjadi petani, pendaki gunung, guru, penyanyi, menjadi apapun yang 
dibayangkan oleh anak. Namun sentra ini pula menjadi momok bagi para guru dikarenakan guru harus kreatif merencanakan pembelajaran sentra bermain peran yang harus disesuiakan dengan tema dan standar tingkat pencapaian perkembangan anak, sehingga beberapa guru kesusahan dalam menyusun kegiatan pembelajaran.

Dari hasil penelitian tentang penerapan model sentra bermain peran untuk meningkatkan kemampuan bersosialisasi pada pendidikan anak usia dini. Hasil Uji menunjukkan bahwa pembelajaran dengan metode bermain peran dapat meningkatkan kemampuan bersosialisasi anak usia dini. Perkembangan sosial anak ditandai oleh kemampuan dalam menyesuaikan diri dan mengembangkan tingkah laku sosialnya sehingga dapat bersosialisasi dengan baik (Nurul Aida, 2015: 78-99). Selain itu (Erma Febriana, 2018: 115) dari hasil penelitian menyebutkan bahwa penerapan model pembelajaran sentra bermain peran di kelas B2 RA Tiara Chandra Yogyakarta telah berhasil dalam menanamkan nilai moral anak. Hal ini dapat dilihat dari tercapainya indikator yang telah di tetapkan oleh RA Tiara Chandra sesuai dengan kurikulum 2013.

Banyaknya sumber ilmiah yang menyatakan bahwa model pembelajaran model sentra bermain peran sangat baik bagi perkembangan anak, namun kondisi di lapangan, dari hasil observasi yang dilakukan di TK kecamatan Kebonarum, Klaten menunjukkan bahwa 9 dari 10 sekolah masih menggunakan model pembelajaran klasikal, sementara 1 sekolah menggunakan model pembelajaran sentra, hal ini berarti bahwa sekolah di kecamatan Kebunarum masih sangat minim pengetahuan bahwa ada model pembelajaran lain yang lebih cocok digunakan pada PAUD. Dari hasil observasi yang telah dilakukan oleh peneliti, di daerah Solo-Klaten membuktikan bahwa dampak atau efek beberapa sekolah menggunakan model sekolah dengan sentra mengalami banyak kendala. Dibeberapa sekolah menunjukan ketidaksiapan menggunakan model sentra, sebagai contoh beberapa sekolah di daerah Solo pada sentra bermain peran tidak melakukan kegiatan bermain peran selayaknya sentra tersebut, guru malah memberikan kegiatan membaca, menulis, berhitung, yang seharusnya ditempatkan di sentra persiapan. Dari segi fasilitas ruangan, seharusnya sentra bermain peran itu memiliki ruangan yang cukup luas sehingga anak bisa bermain peran dengan nyaman, namun beberapa sekolah sentra yang ada tidak memiliki ruangan tersendiri untuk sentra bermain peran.

Hasil observasi awal menunjukkan perbedaan di sekolah TK IT Al-Hasna Klaten, sekolah ini melakukan kegiatan sentra bermain peran dilaksanakan dengan baik dan sudah menggunakan bermain peran mikro dan makro dalam setiap pembelajaran sentra main peran, sekolah juga memiliki ruangan khusus untuk sentra peran, dan sekolah ini memang menjadi rujukan bagi sekolah-sekolah lain untuk melakukan studi banding memperoleh ilmu tentang model pembelajaran sentra. Oleh karena itu, peneliti tertarik untuk meneliti tentang model pembelajaran sentra bermain peran yang ada di TK IT Al-Hasna Klaten dan penelitian ini juga dilakukan untuk mengetahui bagaimana pembelajaran yang diberikan dengan menggunakan model sentra bermain peran. 


\section{METODE PENELITIAN}

Penelitian dilakukan pada guru sentra bermain peran dan kepala sekolah di TK IT Al-Hasna Klaten. Penelitian menggunakan purposive sampel, dimana guru yang menjadi subjek penelitian hanya guru sentra bermain peran yang sudah menjadi guru sentra peran selama beberapa tahun di sekolah dan kepala sekolah di TK tersebut. Metode penelitian yang digunakan adalah penelitian metode deskriptif dengan pendekatan kualitatif. Teknik pengumpulan data yang digunakan adalah wawancara, observasi dan dokumentasi, sedangkan alat pengumpul data penelitian adalah pedoman wawancara, lembar observasi dan dokumentasi. Kegiatan pelaksanaan penelitian dimulai dengan menyusun instrumen penelitian seperti panduan observasi, panduan wawancara, dan dokumentasi. Observasi dilakukan pada performance guru ketika mengajar di sentra main peran. Wawancara dilakukan kepada kepala sekolah dan guru. Wawancara kepada kepala sekolah terkait hasil pijakan yang ada di sentra bermain peran. Proses pengumpulan data peneliti terjun ke sekolah untuk melakukan observasi, wawancara mendalam dan dokumentasi kepada responden terkait dengan pelaksanaan model pembelajaran sentra bermain peran oleh guru. Tahap selanjutnya yakni tahap analisis data. Data dianalisis menggunakan teknik model Miles dan Huberman yaitu, reduksi data, penyajian data, dan penarikan kesimpulan. Analisis dan pengolahan data berpedoman pada data yang terkumpul dari pertanyaan penelitian. Data kualitatif dari penelitian ini yaitu hasil observasi, wawancara, dan dokumentasi. Data hasil observasi, wawancara dan dokumentasi yang terkumpul dianalisis secara deskriptif. Hasil analisis data disajikan dalam bentuk laporan penelitian (Nahdi \& Yunitasari, 2019; Ramdhani et al., 2019).

\section{HASIL DAN PEMBAHASAN}

\section{Implementasi model sentra bermain peran di TK AL-Hasna}

Dari hasil wawancara kepada kepala sekolah, TK IT Al-Hasna pada awal pendiriannya masih menggunakan model klasikal dikarenakan jumlah ruangan yang terbatas dan guru-guru yang belum kompeten. Namun seiring berjalan waktu pihak sekolah menyadari bahwa model pembelajaran klasikal ternyata tidak bisa memberikan sebuah pembelajaran yang berpusat pada anak. Dengan model klasikal guru lebih banyak aktif dibandingkan anak di dalam kelas, sehingga kepala sekolah mengikuti berbagai pelatihan model pembelajaran sentra. Sejak diterapkan model pembelajaran sentra, sekolah sudah banyak memiliki prestasi membanggakan yang telah dicapai dalam perlombaan di lingkup kecamatan, maupun tingkat kabupaten. Hal ini tidak lepas karena model pembelajaran sentra memberikan kesempatan kepada anak sebagai anak menjadi pembelajar yang aktif, anak dapat mengembangkan minat dan bakat yang telah dimilikinya dengan baik melalui model sentra. Selain prestasi dari anak, dari pihak guru dan kepala sekolah juga menjuarai berbagai perlombaan yaitu salah satu pendidik bu Istiqomah, S. Pd menjadi guru teladan di Kabupaten Klaten, dan kepala sekolah 
bu Ratih Tari Munandar, S. Pd juara 1 kepala sekolah berprestasi di kabupaten Klaten pada tahun 2019.

TK IT Al-Hasna membuka beberapa sentra di kelompok B antara lain: sentra seni, sentra balok, sentra imtaq, sentra persiapan, sentra main peran, dan sentra bahan alam cair. Salah satu sentra unggulan di TK IT Al-Hasna adalah sentra bermain peran, hal ini karena sentra bermain peran juga dikaitkan jalan cerita dengan nilai-nilai dan moral agama yang sangat bagus untuk perkembangan anak. Sekolah juga memiliki ruangan yang cukup luas untuk anak bermain dan bereksplorasi dalam sentra bermain peran, sehingga anak dapat mengembangkan daya ingat, berimajinasi, berekspresi,bereksplorasi serta perkembangan nilai-nilai agama dan moral juga akan terbentuk pada diri anak. Penekanan pada sentra ini adalah terletak pada bagaimana anak mengeksplorasikan diri sebaik-baiknya. Tujuan pada sentra ini adalah agar anak dapat bersosialisasi, berinteraksi dengan temannya serta menumbuhkan nilai-nilai yang luhur pada diri anak. Hal ini sesuai dengan penelitian (Erma Febriana, 2018: 115) dari hasil penelitian menyebutkan bahwa penerapan model pembelajaran sentra bermain peran di kelas B2 RA Tiara Chandra Yogyakarta telah berhasil dalam menanamkan nilai moral anak. Hal ini dapat dilihat dari tercapainya indikator yang telah di tetapkan oleh RA Tiara Chandra.

TK IT Al-Hasna memiliki 3 kelas B yang terdiri dari B1, B2, dan B3, masing-masing kelas ini memiliki ruang kelas tersendiri yang cukup luas, kelas dibagi dan disekat semi permanen menggunakan rak buku menjadi 2 bagian. B1 menjadi ruang kelas sentra seni dan sentra balok. B2 sentra bahan alam dan sentra persiapan. B3 menjadi sentra bermain peran, sedangkan sentra imtaq berada di samping mushola. Sentra bermain peran merupakan sentra yang memiliki ruangan yang lebih luas dibandingkan sentra-sentra yang lain. Dalam 1 kelas B1, B2, dan B3 anak juga dibagi menjadi 2 kelompok, jadi total kelas B ada 6 kelompok. 6 kelompok inilah dalam 1 hari memasuki 1 sentra yang sudah dijadwalkan sebelumnya. Dalam 1 kelompok anak terdiri dari 8-10 anak, sehingga masing-masing sentra diampu oleh 1 guru sentra dengan 8-10 anak. Sentra bermain peran memiliki 4-5 ragam main atau kegiatan dalam 1 hari, dan anak diminta untuk mencoba semua ragam main tersebut dalam 1 hari.

Diawal tahun pembelajaran guru dan kepala sekolah sudah menyiapkan promes, RPPM, RPPH sesuai dengan sentranya masing-masing. Di sentra bermain peran guru menyiapkan 4 kegiatan yang sesuai dengan tema dan disesuaikan sentranya, kegiatan ini dibuat guru sentra bermain peran kemudian dikonsultasikan kepada kepala sekolah apakah kegiatan sesuai dengan tema dan sentra main peran, apabila sudah cocok maka guru sentra dapat membuat kegiatan-kegiatan tersebut di sentra main peran.

Untuk tema, guru memang sudah menyiapkan tema pada saat membuat program semester diawal semester, namun dari hasil wawancara guru dan kepala sekolah menyatakan bahwa subtema ini terkadang adalah pilihan dari anak, contohnya dengan tema lingkunganku guru memberi beberapa gambar kepada anak kemudian anak dan guru mendiskusikan bersama kira-kira subtema apa yang 
paling disukai anak, guru memiliki tema lingkungan, dari tema lingkungan tersebut guru memecah menjadi subtema, pada saat observasi anak lebih memilih gunung dibandingkan subtema lain seperti laut dan air terjun, guru beranggapan bahwa anak memilih subtema gunung karena gunung adalah hal yang sangat dekat bagi anak, mengingat di Klaten sendiri memiliki daerah gunung merapi, dan ketika anak jalan-jalan pagi hari anak melihat secara langsung gunung merapi dan gunung merbabu yang saling bersebelahan.

Pada saat observasi pertama, tema hari itu adalah lingkunganku dengan subtema gunung. Kemudian subtema ini dijadikan dasar guru untuk membuat kegiatan. Kegiatan pada saat observasi di sentra peran adalah anak berpura-pura atau bermain peran menjadi seorang pendaki gunung dan melakukan camping di gunung, awalnya guru sudah menyeting ruang kelas seperti suasana berkemah digunung, guru menggunakan bahan yang seadaanya seperti kursi dan kain sprei yang lebar kemudian dibentangkan sehingga membentuk sebuah tenda kemah sederhana, 4 kegiatan yang harus dilakukan oleh anak secara bergiliran adalah, membuat api unggun, mengumpulkan sampah yang ada di gunung, memasak makanan untuk sarapan pendaki, dan membersihkan tenda.

Kegiatan main yang dilakukan disentra main peran adalah kegiatan yang bersifat pura-pura, contohnya saat membuat api unggun guru menggunakan kayu ranting pohon dan balok-balok yang ada di sekolah, kemudian anak diminta menyusun agar ranting dan balok ini bisa membentuk seperti api unggun, anak diminta berpura-pura menyalakan korek api kemudian menghangatkan tangannya di api unggun buatan anak. Kegiatan yang lain adalah mengumpulkan sampah yang ada digunung, pada kegiatan ini guru sudah menyiapkan berbagai macam sampah yang disebar dilantai, seperti daun-daun, ranting, botol, plastik, kemudian anak diminta untuk mengumpulkan sampah organik dan anorganik. Kegiatan ketiga yaitu memasak makanan untuk sarapan, disini guru menyiapkan properti memasak seperti kompor-komporan, penggorengan, dan properti bahan masak kemudian anak bermain peran seperti sedang memasak sebuah masakan. Kegiatan terakhir kegiatan membersihkan tenda, guru menyiapkan properti utuk membersihkan tenda kemudian anak melakukan kegiatan untuk membersihkan tendanya.

Dari hasil observasi selain dengan subtema gunung, guru juga membuat kegiatan dengan subtema "car free day", dari subtema ini guru menyiapkan ruangan seperti situasi yang sama seperti "car free day", 4 kegiatan yang dibuat oleh guru adalah: anak berperan menjadi pedagang sosis bakar, disini alat yang digunkan adalah plastisin untuk membuat sosis dan baksi bakar, tusuk lidi sebagai tusukan sate sosis, properti alat memanggang dan kipas sate. Kegiatan kedua adalah anak berperan menjadi tukang menghias tangan dengan henna, jadi ada anak yang menghias dan yang dihias, anak bergantian memainkannya, ada pula panggung musik, disini anak diminta menjadi penyanyi dan penonton. Jadi kondisi setting kelas memang diatur agar sesuai dengan tema dan kegiatan yang akan dilakukan oleh anak. 


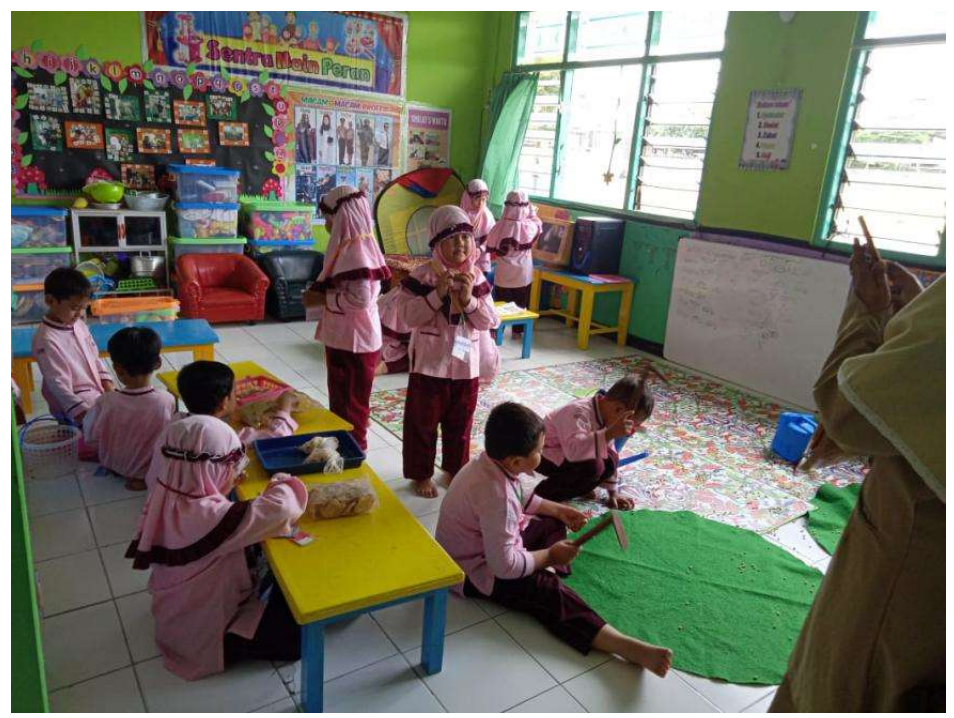

Gambar 1. Anak-anak kelompok B bermain sentra peran

\section{Langkah-langkah kegiatan yang dilakukan dalam pembelajaran di sentra main peran}

Pendekatan sentra dan lingkaran merupakan pendekatan penyelenggaraan PAUD yang berfokus pada anak yang dalam proses pembelajarannya berpusat di sentra main dan saat anak dalam lingkaran dengan menggunakan 4 jenis pijakan (scaffolding) untuk mendukung perkembangan anak, yaitu: pijakan lingkungan main, pijakan sebelum main, pijakan selama main, pijakan setelah main. Pijakan adalah dukungan yang berubah-ubah yang disesuaikan dengan perkembangan anak yang diberikan untuk mencapai perkembangan anak yang lebih tinggi. Secara lebih detail penjelasan empat pijakan tersebut menurut (Asmawati, 2014: 52-54) adalah sebagai berikut :

pijakan lingkungan main dapat dipersiapkan guru dengan cara: mengelola lingkungan main sentra dengan bahan dan jumlah jenis yang cukup, merencanakan intensitas permainan, memiliki dan menyediakan bahan pendukung 3 jenis main, memiliki bahan pendukung pengalaman keaksaraan, menata kesempatan main untuk mendukung hubungan sosial pijakan pengalaman sebelum main (selama 15 menit) dengan cara: bersama anak duduk melingkar, memberi salam dan menanyakan kabar kepada anak-anak, meminta anak-anak untuk memperhatikan temannya yang tidak hadir, dan kegiatan pembukaan lainnya. pijakan selama anak main (60 menit) dengan cara memberikan anak waktu untuk mengelola dan memperluas pengalaman main mereka, berkeliling antara anak-anak yang sedang bermain, mencontohkan komunikasi yang tepat, memberi bantuan kepada anak yang membutuhkan, mendorong anak untuk mencoba permainan lain, memberitahukan kepada anak-anak bahwa kurang 5 menit sentra akan selesai. pijakan setelah bermain (30 menit) dengan cara mendukung anak untuk mengingat kembali pengalaman mainnya dan menceritakan pengalaman tersebut, anak diajak untuk merapikan kembali mainan yang telah digunakan. 
Dari pendapat Asmawati tersebut yang menyatakan bahwa model sentra akan bisa berjalan dengan maksimal jika keempat pijakan dilaksanakan, dari hasil observasi dan wawancara menunjukkan bahwa TK IT AL-Hasna sudah melaksanakan 4 pijakan main tersebut dan dilakukan setiap hari secara rutin, berikut ini adalah jadwal rutin yang dilakukan oleh sekolah selama satu hari dari mulai penyambutan kelas sampai kegiatan akhir penutup.

\section{Kegiatan Sebelum Masuk kelas atau Penyambutan Anak}

Guru menyambut kedatangan anak dengan tegur sapa, senyum dan salam. Anak-anak langsung diarahkan untuk bermain bebas bersama teman-teman sambil menunggu kegiatan dimulai. Kondisi awal yang harus diketahui oleh guru dan peserta didik saat datang adalah ekspresi emosi yang menunjukkan rasa nyaman berada di sekolah. Bila kondisi ekspresi emosi anak saat datang menunjukkan kesedihan atau murung, maka guru perlu menetralisir emosi anak terlebih dahulu dengan kegiatan transisi, seperti membaca buku cerita, puzzle, dan sebagainya. Guru juga bertugas untuk menanyakan kabar anak yang terlihat murung, anak diajak bercakap-cakap dan ditanyakan kenapa bersedih atau ada permasalahan sehingga anak merasa bahwa ada yang mau mendengarkan keluh kesah anak.

\section{Pembukaan atau Pengalaman Gerakan Kasar}

Setelah pukul 07.30 kegiatan rutin adalah upacara, namun istilah upacara ini bukan seperti upacara bendera seperti di SD atau kelas tinggi, upacara ini adalah kegiatan motorik kasar seperti senam atau permainan-permainan outdoor secara berkelompok, seperti main kucing dan tikus, main lempar tangkap bola, main berjalan diatas titian dll. Guru menyiapkan seluruh anak dalam lingkaran, lalu menyebutkan kegiatan pembuka yang akan dilaksanakan. Kegiatan pembuka dapat berupa gerak musik, permainan, senam, dan sebagainya. Satu guru yang memimpin, guru lainnya menjadi peserta bersama anak (mencontohkan). Setelah selesai kegiatan fisik anak diminta untuk masuk kedalam sentra sesuai dengan jadwalnya. Setelah masuk disentra peran anak dikondisikan duduk melingkar (circle time). Dalam setiap kelompok melakukan kegiatan berdoa, diskusi tema, membacakan buku cerita yang berhubungan dengan tema pada hari itu.

Selesai pembukaan, anak-anak diberi waktu untuk "pendinginan" dengan cara bernyanyi dalam lingkaran, atau membuat permainan tebak-tebakan. Tujuannya agar anak kembali tenang. Setelah tenang, anak secara bergiliran dipersilahkan untuk minum atau ke kamar kecil. Para Guru munakan kesempatan ini untuk melatih kebersihan diri anak. Kegiatannya dapat berupa cuci tangan, cuci muka, cuci kaki maupun buang air kecil. Sambil menunggu anak minum atau ke kamar kecil, masing-masing guru siap di tempat bermain yang sudah disiapkan untuk kelompoknya masing-masing.

\section{Pijakan Sentra}

Pijakan lingkungan main adalah pijakan yang dilakukan guru sebelum anak didik masuk kedalam sentra bermain peran, tugas guru adalah menyiapkan setting kelas serta ragam main yang akan dilakukan oleh anak di dalam sentra. Sebelum 
pukul 07.00 guru sudah harus menyeting kelas sesuai dengan tema pada hari itu, jika ada 4 ragam main guru juga menyiapkan dari media, alat, dan bahan yang akan digunakan. (1) Guru dan anak duduk melingkar, guru memberi salam pada anak-anak, kabar anak-anak, dan dilanjutkan dengan kegiatan; (2) Guru meminta anak untuk memperhatikan siapa teman yang tidak hadir. Minta anak mengambil "nametag" dan menempelkan ke papan absen, membalik, atau menunjukkan. Bisa pula absensi anak menggunakan lagu-lagu sehingga anak semangat diawal kegiatan; (3) Berdoa bersama, anak secara bergilir memimpin doa. Di TK Al-Hasna terdapat unggulan program lain yaitu hafalah surat dan hadist, sehingga setelah berdoa anak anak muraja'ah surat dan hadist-hadist pendek (4) Guru menyampaikan tema hari ini dan dikaitkan dengan kehidupan anak. Kemudian anak dan guru melakukan percakapan mengenai tema yang telah disampaikan; (5) Guru mengenalkan semua tempat dan alat bermain yang sudah disiapkan. Disini terdapat 4 kegiatan dalam sentra bermain peran; (6) Dalam memberi pijakan, guru harus mengaitkan kemampuan apa yang diharapkan muncul pada anak, sesuai rencana pembelajaran yang telah disusun.; (7) Guru menyampaikan bagaimana aturan bermain (digali dari anak) jadi aturan main dibuat bersama antara guru dengan anak, memilih teman bermain, memilih alat bermain, cara menggunakan alat-alat, kapan memulai dan mengakhiri bermain, serta merapikan kembali alat yang sudah dimainkan; (8) Guru mengatur teman lain dengan memberi kesempatan kepada anak untuk memilih teman mainnya. Apabila ada anak yang hanya memilih anak tertentu sebagai teman mainnya, maka guru agar menawarkan untuk menukar teman mainnya (9) Setelah anak siap bermain, guru mempersilahkan anak untuk mulai bermain. Agar tidak berebut serta lebih tertib, guru dapat menggilir kesempatan setiap anak untuk mulai bermain, misalnya berdasarkan warna baju, usia anak, huruf depan nama anak, atau cara lainnya agar lebih teratur.

Pijakan Pengalaman Selama Bermain diantaranya : (1) Guru mengamati dan memastikan semua anak melakukan kegiatan bermain; (2) Memberi contoh cara bermain pada anak yang belum bisa menggunakan bahan alat (3) Memberi dukungan berupa pernyataan positif tentang pekedaan yang dilakukar anak (4) Memancing dengan pertanyaan terbuka untuk memperluas cara bermain anak Pertanyaan terbuka artinya pertanyaan yang ticlak cukup dengan dijawab ya ata tidak saja, tetapi banyak kemungkinan jawaban yang dapat diberikan anak (5) Memberikan bantuan pada anak yang membutuhkan; (6) Mendorong anak untuk mencoba dengan cara lain, sehingga anak memilik pengalaman bermain yang kaya (7) Mencatat yang dilakukan anak jenis bermain, tahap perkembangan, tahapan sosial, catatan ini yang akan menjadi hasil evaluasi pada anak (8) Mengumpulkan hasil kerja anak. Jangan lupa mencatat nama dan tanggal lembar kerja anak; dan (9) Bila waktu tinggal 5 menit, guru memberitahukan pada anak-anak untuk bersiap-siap menyelesaikan kegiatan mainnya.

Pijakan Pengalaman Setelah Bermain diantaranya adalah : (1) Apabila waktu bermain selesai, guru memberitahukan saatnya membereskan alat dan bahan yang sudah digunakan melibatkan anak-anak. Terkadang untuk membuat anak semangat guru memancing anak membereskan mainan dengan metode 
bernyanyi (2) Bila anak belum terbiasa untuk membereskan, guru dapat membuat permainan yang menarik agar anak ikut membereskan Saat membereskan, guru menyiapkan tempat yang berbeda untuk setiap jenis alat, sehingga anak dapat mengelompokkan alat bermain sesuai dengan tempatnya (3) Bila bahan mainan sudah dirapikan kembali, satu guru membantu anak membereskan baju anak (menggantinya bila basah) (4) Bila anak sudah rapi mereka diminta duduk melingkar bersama guru. Setelah semua anak duduk dalam lingkar, guru menanyakan pada setiap anak apakah anak bahagia pada hari itu, apa saja kegiatan bermain yang telah dilakukan pada hari itu. Kegiatan menanyakan kembali (recalling) melatih daya ingat anak mengemukakan gagasan dan pengalaman mainnya (memperluas perbendaharaan kata anak).

Proses kegiatan selanjutnya adalah makan Bersama. Kegiatan makan Bersama tersebut diantaranya adalah : (1) Setiap pertemuan ada kegiatan makan bersama. Jenis makanan nasi atau makanan lainnya yang disiapkan sekolah. Anak diminta untuk mengambil sendiri makanan dan lauknya, dengan konsekwensi bahwa anak harus menghabiskan makanan karena anak mengambil sendiri (2) Guru memberitahukan jenis makanan yang disediakan adalah makanan yang baik, jadi anak harus mengambil semua jenis makanan terutama sayur yang baik untuk kesehatan anak; (3) Jadikan waktu makanan bersama sebagai pembiasaan tata cara makan yang baik (adab makan). Anak kelas B sudah diminta untuk menghabiskan makanan yang telah diambil sendiri (4) Ikut melibatkan anak pada saat membereskan bekas makanan dan membuang bungkus makanan ke tempat sampah. Anak kelas B diminta untuk mencuci piringnya sendiri kemudian diletakkan dirak piring

Kegiatan penutupnya adalah : (1) Setelah semua anak berkumpul membentuk lingkaran, guru dapat mengajak anak menyanyi atau membaca puisi. Guru menyampaikan rencana kegiatan hari berikutnya, dan menganjurkan anak untuk bermain yang sama di rumah masing-masing (2) Guru memberi kesempatan kepada anak secara bergiliran untuk memimpin doa penutup (3) Untuk menghindari berebut saat pulang, digunakan urutan berdasarkan warna baju, usia, atau cara lain untuk keluar dan bersalaman lebih dahulu.

Langkah-langkah inilah yang dilakukan anak dalam satu hari ketika anak masuk kedalam sentra permain peran, hari berikutnya anak akan memasuki sentra lain sesuai dengan jadwalnya, dan sentra peran diisi oleh kelompok anak lain yang belum ke sentra permain peran, sistem inilah yang dinamakan sebagai sistem rolling, jadi anak yang berputar atau berpindah sentra sedangkan guru dan kegiatan menetap dalam satu tempat.

\section{Media sentra bermain peran}

Dari hasil observasi dan wawancara menunjukkan bahwa sekolah memiliki beberapa alat main peran yang sudah menunjang pembelajaran baik main peran mikro maupun main peran makro, sekolah memiliki beberapa set mainan mini dokter-dokteran, seperti stetoskop, termometer, id card dokter, set maianan pertanian seperti miniatur cangkul, caping, alat penyiram tanaman, set mainan tukang, boneka atau mobil-mobilan. Menurut Yusuf (2015: 13-14) main peran 
kecil mengembangkan kemampuan berpikir abstrak, kemampuan berbahasa, sosial-emosional, menyambungkan pengetahuan yang sudah dimiliki dengan pengetahuan baru dengan menggunakan alat main peran berukuran kecil. Alat dan Bahan yang digunakan antara lain: berbagai miniatur mainan, berbagai mainan alat rumah tangga, berbagai mainan mini alat kedokteran, berbagai mainan mini alat transportasi berbagai mainan mini alat tukang. Sedangkan sentra main peran besar mampu mengembangkan kemampuan mengenal lingkungan sosial, mengembangkan kemampuan bahasa, kematangan emosi dengan menggunakan alat main yang berukuran besar sesuai dengan ukuran sebenarnya contoh medianya mainan untuk pasar-pasaran, mainan untuk rumah-rumahan, mainan untuk dokter-dokteran, mainan untuk kegiatan pantai, mainan untuk tukang-tukangan, mainan untuk kegiatan nelayan, mainan salon-salonan.

Namun ketika tema yang dibuat ternyata sekolah tidak memiliki media yang tepat, sebagai contoh ketika di sentra peran bermain menjadi pendaki guru membutuhkan sebuah tenda kemah, guru kesulitan karena memang sekolah tidak mempunyai tenda kemah, setelah berkonsultasi dengan kepala sekolah, kepala sekolah menyarankan agar membuat tanda-tenda dengan bahan-bahan yang tersedia seperti kain sprei yang kemudian diikat dengan kursi sehingga seperti sebuah tenda sederhana, jadi guru seharusnya mampu berkreasi dengan berbagai sumber alat yang sederhana sehingga menghasilkan sebuah alat permainan yang menarik bagi anak.

\section{Evaluasi model sentra bermain peran}

Evaluasi perkembangan anak di TKIT Al-Hasna di lakukan setiap hari, setiap kelompok yang datang disentra main peran sudah membawa alat penilaian berupa checklist yang akan diisi oleh guru sentranya. Jadi ketika anak bermian dalam sentra guru bertugas sebagai fasilitator sekaligus sebagai evaluator bagi anak. Setiap kelompok memiliki grup whatsap yang setiap guru akan melaporkan kegiatan anak setiap harinya. Untuk formalnya laporan perkembangan anak diberikan kepada wali murit satu bulan sekali dalam bentuk print out. Untuk penilaian semester berupa raport yang disertai gambar atau dokumentasi kegiatan anak yang dicetak dengan kualitas yang lebih baik agar lebih awet. dan bagi anak yang ingin melanjutkan ke jenjang pendidikan lanjutan raport akan disertai surat keterangan. Evaluasi perkembangan anak ini dilaporkan kepada orang tua. Penilaian diambil berdasarkan penilaian dari para pendidik terhadap hasil karya anak dan perilaku yang di tunjukkan oleh anak sehari hari.

\section{Faktor pendukung dan kendala model sentra bermain peran}

Faktor pendukung pada implementasi model sentra peran yang pertama adalah kompetensi kepala sekolah yang baik, ini terbukti bahwa kepala sekolah di TKIT Al-Hasna adalah kepala sekolah berprestasi tingkat kabupaten sehingga guru-guru memperoleh bimbingan yang baik dari kepala sekolah, faktor pendukung yang kedua adalah ruang kelas sentra bermain peran yang luas sehingga anak bisa berkeplorasi dengan baik. Namun proses pembelajaran sentra bermain peran tidak terlepas dari berbagai kendala diantaranya yaitu: 
Kurangnya guru yang kreatif. Guru merupakan salah satu faktor utama yang bisa membuat seorang anak memiliki pengetahuan dan keterampilan yang lebih baik. Masalah terjadi saat guru yang bertugas untuk mendidik anak-anak tidak semua berasal dari lulusan ke-PAUDan. Ketika guru menyusun kegiatan sentra guru peran terkadang masih kesulitan dengan penyusunan kegiatannya, sehingga guru sering diberikan tuntunan dari kepala sekolah agar kegiatan menjadi lebih sesuai dan menarik. Kendala yang kedua adalah pengadaan media belajar mengajar masih terus dikembangkan dan diinovasi sedemikian rupa agar pembelajaran selalu up date dan selaras dengan perkembangan zaman. Sekolah hanya memiliki beberapa media main peran yang sudah sering dimainkan, sedangkan tema-tema tertentu sekolah masih belum memiliki. Kendala ini dari hasil wawancara kepada kepala sekolah, guru yang bertugas memegang sentra harus sering diikutkan workshop dan pelatihan agar keterampilan mereka bisa berkembang, beberapa guru juga dituntun untuk melakukan pendidikan penyetaraan agar ilmu kePAUDan mereka bisa berkembang sehingga guru-guru ini menjadi guru yang kreatif dan terampil(Amalia, 2018.; Astuti, 2016; Rahayu, 2016) .

\section{KESIMPULAN}

Model pembelajaran sentra main peran yang dilaksanakan di TK IT Al-Hasna sudah dilakukan dengan baik. Guru melakukan 4 pijakan yang ada dalam model sentra, yaitu pijakan lingkungan main, pijakan sebelum main, pijakan selama main dan pijakan setelah main. Pijakan ini sudah menjadi rutinitas wajib bagi sekolah. Kegiatan yang dilakukan juga sudah sesuai dengan tema, subtema dan sesuai dengan sentranya, sentra bermain peran difungsikan sangat baik karena semua kegiatan di sentra main peran adalah anak bermain peran sesuai dengan aturan dan kreativitas anak. Faktor pendukung dalam implementasi model main peran adalah kompetensi kepala sekolah yang baik serta luasnya ruangan sentra bermain peran. Sedangkan faktor penghambat adalah guru yang kurang kreatif dan media pembelajaran yang masih kurang.

\section{DAFTAR PUSTAKA}

Aida, N. (2015). Penerapan Metode Bermain Peran Untuk Meningkatkan Kemampuan Bersosialisasi Pada Pendidikan Anak Usia Dini. Jurnal Psikologi Indonesia Vol. 4, No. 01

Alif, A., \& Wulantika, W. (2020). Penerapan Pembelajaran Berbasis Sentra Bermain Peran Terhadap Perkembangan Sosial Emosional Pada Anak Usia Prasekolah. In Jurnal Seminar Nasional Pendidikan. Hlm (Pp. 31-33).

Andresen, H. (2005). Role Play And Language Development In The Preschool Years. Culture \& Psychology. Vol. 11(4): 387-414

Amalia, T. Z. (N.D.). Mengajar Bagi Guru Raudlatul Usia Dini Di Desa Ngembalrejo. 28(2). 
Astuti, S. K. (2016). Pelaksanaan Pembelajaran Membaca Permulaan DI Kelompok A Taman Kanak-Kanak Aba Pendowo. Jurnal Pendidikan Guru Pendidikan Anak Usia Dini, 3, 194-204

Febriana, E. (2018). Implementasi Sentra Bermain Peran Untuk Menanamkan Nilai Moral Anak. Golden Age. Vol3 (2).

Hamzah. (2009). Teori Motivasi Dan Pengukurannya. Jakarta: Bumi Aksara.

Jafar, F. S., \& Satriana, M. (2018). Penerapan Model Pembelajaran Sentra Dalam Pengembangan Kecerdasan Bahasa Ekspresif Anak Usia Dini. Jurnal Psikologi TALENTA, 4(1), 51-59.

Martuti A. (2010). Mendirikan Dan Mengelola Paud Manajemen Administrasi Dan Strategi Pembelajaran. Yogyakarta: Kreasi Wacana

Mead, H. (1934). Mind, Self And Society: From The Standpoint Of A Social Behaviorist. Chicago, IL: University Of Chicago Press

Mottweiler, Taylor, C. M., Marjorie. (2014) Elaborated Role Play And Creativity In Preschool Age Children. Psychology Of Aesthetics, Creativity, And The Arts, Vol 8(3).

Munastiwi, E. (2019). Peran Guru Dalam Mengembangkan Kreativitas Anak Usia Dini Di TK Islam Terpadu Salsabila Al-Muthi'in Yogyakarta. GOLDEN AGE: Jurnal Ilmiah Tumbuh Kembang Anak Usia Dini, 4(2), 35-50.

Nahdi, K., \& Yunitasari, D. (2019). Literasi Berbahasa Indonesia Usia Prasekolah: Ancangan Metode Dia Tampan Dalam Membaca Permulaan. Jurnal Obsesi: Jurnal Pendidikan Anak Usia Dini, 4(1), 446. Https://Doi.Org/10.31004/Obsesi.V4i1.372

Noorlaila, I. (2010). Panduan Lengkap Mengajar PAUD. Yogyakarta: Pinus Book

Rahayu, Y. M. (2016). Pengaruh Perubahan Kurikulum 2013 Terhadap Perkembangan Peserta Didik. Jurnal Logika, XVIII(3), 33-35.

Ramdhani, S., Yuliastri, N. A., Sari, S. D., \& Hasriah, S. (2019). Penanaman Nilai-Nilai Karakter Melalui Kegiatan Storytelling Dengan Menggunakan Cerita Rakyat Sasak Pada Anak Usia Dini. Jurnal Obsesi: Jurnal $\begin{array}{llll}\text { Pendidikan Anak Usia } & 153 .\end{array}$ Https://Doi.Org/10.31004/Obsesi.V3i1.108

Utami, N. R., \& Sakti, S. A. (2019). Model Pembelajaran Pitutur Luhur Berbasis Multirepresentasi Sebagai Pembentuk Kecerdasan Emosional Anak Usia 5-6 Tahun (Studi Analisis Kebutuhan Pada Guru Taman Kanak-Kanak Di Kabupaten Bantul Yogyakarta). Jurnal Golden Age, 3(02), 84-94.

Widyatmoko, A. (2011). Draf Juklak Model Pembelajaran Sentra Main Peran Pendidikan Anak Usia Dini (PAUD). Yogyakarta : SKB Kab. Sleman

Yusuf, F. (2015). Pedoman Pengelolaan Kelas Pendidikan Anak Usia Dini. Kementerian Pendidikan Dan Kebudayaan Direktorat Jenderal Pendidikan Anak Usia Dini Dan Pendidikan Masyarakat: Direktorat Pembinaan 
Jurnal Golden Age, Universitas Hamzanwadi

Vol. 04 No. 1, Juni 2020, Hal. 167-181

E-ISSN : 2549-7367

Pendidikan Anak Usia Din 